\title{
PERTUMBUHAN DAN PRODUKSI TANAMAN KEDELAI VARIETAS ARGOMULYO TERHADAP PEMBERIAN PUPUK NPK
}

\section{SOYBEAN PLANT GROWTH AND PRODUCTION OF ARGOMULYO VARIETY ON NPK FERTILIZATION}

\author{
Nur Trias Wijayanti ${ }^{1)}$, Tri Wardhani ${ }^{1)}$ dan Untung Sugiarti ${ }^{1)}$ \\ ${ }^{1)}$ Program Studi Agroteknologi, Fakultas Pertanian, Universitas Widyagama Malang, \\ Email: nurtriaswijayanti@gmail.com
}

\begin{abstract}
ABSTRAK
Konsumsi kedelai di Indonesia dalam setahun mencapai 2,25 juta ton, sementara jumlah produksi nasional hanya mampu memasok kebutuhan kedelai sekitar 779 ribu ton. Kekurangan pasokan sekitar 1,4 juta ton, ditutup dengan impor dari Amerika Serikat dan Brazil yang mencapai 70-80\% dari kebutuhan total. Peningkatan produksi kedelai dapat dilakukan dengan pengelolaan tanah yang baik, pemupukan dan pemeliharaan tanaman. Nitrogen, fosfat, dan kalium dari pertumbuhan awal sampai akhir terus diperlukan oleh tanaman kedelai. Pemupukan NPK majemuk merupakan pemberian unsur hara yang lebih efisien dibanding pemupukan tunggal. Penggunaan pupuk NPK majemuk dapat menjadi solusi dan alternatif dalam meningkatkan pertumbuhan tanaman hijauan khususnya tanaman kedelai. Penelitian ini merupakan penelitian eksperimental dengan tujuan untuk mengetahui dosis pemberian pupuk NPK terhadap pertumbuhan dan produksi tanaman kedelai. Rancangan percobaan dalam penelitian ini menggunakan Rancangan Acak Kelompok. Variabel pengamatan tanaman kedelai adalah: tinggi tanaman, jumlah daun, bobot 100 biji kedelai, jumlah polong isi, serapan $\mathrm{N}, \mathrm{P}$ dan $\mathrm{K}$ pada tanaman kedelai. Hasil analisis menunjukkan bahwa perlakuan pupuk NPK pada dosis $300 \mathrm{~kg} / \mathrm{ha}$ berpengaruh signifikan terhadap tinggi tanaman, jumlah daun, bobot 100 kedelai, jumlah polong isi dan serapan $\mathrm{N}$ total.
\end{abstract}

Kata kunci: kedelai; NPK; argomulyo; serapan

\section{ABSTRACT}

Soybean consumption in Indonesia in a year reaches 2.25 million tons, while the total national production is only able to supply around 779 thousand tons of soybeans. The shortage of supply was around 1.4 million tons, covered by imports from the United States and Brazil which reached $70-80 \%$ of the total demand. Increased soybean production can be done with good soil management, fertilization and plant maintenance. Nitrogen, phosphate, and potassium from early to late growth continue to be needed by soybean plants. Multiple NPK fertilization is the provision of nutrients that is more efficient than single fertilization. The use of compound NPK fertilizers can be a solution and alternative in increasing the growth of forage plants, especially soybeans. This research is an experimental study with the aim of knowing the dose of NPK fertilizer on the growth and production of soybean plants. The experimental design in this study used a Randomized Block Design. Variables observed for soybean plants were: plant height, number of leaves, weight of 100 soybean seeds, number of filled pods, $N, P$ and $K$ uptake in soybean plants. The results of the 
analysis showed that the treatment of NPK fertilizer at a dose of $300 \mathrm{~kg} / \mathrm{ha} \mathrm{had} \mathrm{a}$ significant effect on plant height, number of leaves, weight of 100 soybeans, number of filled pods and total $N$ uptake.

Keywords: soybean; NPK; argomulyo; uptake

\section{PENDAHULUAN}

Kedelai merupakan tanaman legum yang kaya protein nabati, karbohidrat dan lemak. Biji kedelai mengandung fosfor, besi, kalsium, vitamin B dengan asam amino lengkap, sehingga potensial untuk pertumbuhan tubuh manusia (Pringgohandoko dan Padmini, 2015).

Kedelai merupakan sumber protein nabati utama bagi sebagian besar penduduk Indonesia. Kedelai memiliki peranan penting yaitu sebagai sumber bahan baku utama tahu dan tempe yang merupakan lauk pauk sebagian besar penduduk yang murah. Bagian tanaman kedelai juga dimanfaatkan sebagai pakan ternak.

Kebutuhan kedelai di Indonesia setiap tahun selalu meningkat seiring dengan pertambahan penduduk dan pendapatan/kapita. Konsumsi kedelai di Indonesia dalam setahun mencapai 2,25 juta ton, sementara jumlah produksi nasional mampu memasok kebutuhan kedelai hanya sekitar 779 ribu ton. Kekurangan pasokan sekitar 1,4 juta ton ditutup dengan kedelai impor dari Amerika Serikat dan Brazil yang mencapai $70-80 \%$ dari kebutuhan total (BPS, 2019).

Peningkatan produksi kedelai dapat diusahakan dengan pengelolaan pengelolaan tanah yang baik, pemupukan dan pemeliharaan tanaman. Pemupukan merupakan tindakan memberikan bahan-bahan organik maupun anorganik yang diberikan pada tanah untuk memperbaiki keadaan fisik tanah tersebut (Haddie, dkk, 2013). Nitrogen, fosfat, dan kalium pada pertumbuhan awal sampai akhir terus diperlukan bagi tanaman kedelai.

Pemupukan NPK majemuk merupakan pemberian unsur hara yang efisien dibanding dengan pemupukan tunggal. Kelebihan pupuk NPK majemuk ditinjau dari segi distribusi, penyimpanan dan aplikasi, pupuk majemuk NPK lebih efisien dari pada pupuk tunggal. 
Pupuk NPK majemuk dapat menjadi solusi dan alternatif dalam meningkatkan pertumbuhan tanaman hijauan khususnya tanaman kedelai. Dalam upaya menghasilkan tanaman kedelai yang berkualitas dengan meningkatkan penyerapan unsur hara tanaman, maka perlu melakukan penelitian tentang pertumbuhan dan produksi tanaman kedelai varietas argomulyo akibat pemberian pupuk NPK

\section{METODE PENELITIAN}

Bahan dan alat yang digunakan dalam penelitian ini adalah benih kedelai Varietas Argomulyo, pupuk NPK, pupuk kandang, pupuk phonska dan insektisida kompidor, alat penyiram, penggaris, sabit, tali rafia dan alat tulis. Percobaan dilaksanakan dengan menggunakan Rancangan Acak Kelompok, sebanyak 6 perlakuan dengan 3 ulangan yaitu:

P1: Kontrol (tanpa pemupukan)

P2: Pupuk tunggal dengan dosis anjuran (urea $50 \mathrm{~kg} / \mathrm{ha}$, SP36 150 kg/ha, KCl 100 kg/ha)

P3: Pupuk majemuk NPK $(15: 15: 15)$

P4: 1/3x dosis pupuk majemuk NPK (10:26:10), yaitu $100 \mathrm{~kg} / \mathrm{ha}$ NPK
P5: 2/3x dosis pupuk majemuk NPK (10:26:10), yaitu $200 \mathrm{~kg} / \mathrm{ha}$ NPK P6: 1x dosis pupuk majemuk NPK (10:26:10), yaitu $300 \mathrm{~kg} / \mathrm{ha}$ NPK.

Lahan tanam yang digunakan adalah lahan sawah, dengan jenis tanah inceptisol yang diambil dari Desa Sukaresmi, Kecamatan Megamendung, Cisarua Bogor. Pengolahan tanah dilakukan dengan mencangkul hingga kedalaman 20 $\mathrm{cm}$. Setelah itu dibuat petakan dengan ukuran $3 \mathrm{mx} 5 \mathrm{~m}$ dengan tinggi bedengan $25 \mathrm{~cm}$ sebanyak 18 petak. Jarak antar ulangan selebar 50 $\mathrm{cm}$, serta jarak parit dengan petak selebar $30 \mathrm{~cm}$. Parameter yang diamati adalah tinggi tanaman, jumlah daun, jumlah polong isi, berat 100 biji kedelai, kadar N-total tanaman, kadar P-total tanaman, dan kadar K-total tanaman. Pengambilan sampel tanaman dilakukan secara acak sebanyak 10 tanaman setiap petak penelitian. Pada pengamatan $\mathrm{N}$, P, dan $\mathrm{K}$ total tanaman, sampel diambil pada bagian batang akar bunga dan daun tanaman kedelai. Analisis data mengunakan analisis ragam (ANOVA), dan jika terdapat 
pengaruh nyata maka dilakukan uji lanjut menggunakan uji Duncan.

\section{HASIL DAN PEMBAHASAN}

\section{Tinggi Tanaman}

$\begin{array}{ccr}\text { Hasil } & \text { analisis } & \text { ragam } \\ \text { menunjukkan } & \text { bahwa } & \text { perlakuan }\end{array}$

pupuk majemuk NPK berpengaruh nyata pada pertumbuhan tinggi tanaman, baik pada umur 3MST, 5MST, 7MST, dan 9MST (Tabel 1).

Tabel 1. Tinggi Tanaman Kedelai Varietas Argomulyo Pada Pemberian Pupuk NPK

\begin{tabular}{ccccc}
\hline Perlakuan & \multicolumn{4}{c}{ Tinggi Tanaman } \\
\cline { 2 - 5 } & 3 MST & $5 \mathrm{MST}$ & $7 \mathrm{MST}$ & $9 \mathrm{MST}$ \\
\hline P1 & $17,86 \mathrm{a}$ & $34,50 \mathrm{a}$ & $57,37 \mathrm{a}$ & $64,30 \mathrm{a}$ \\
P2 & $20,25 \mathrm{c}$ & $41,09 \mathrm{~b}$ & $68,50 \mathrm{~b}$ & $81,13 \mathrm{c}$ \\
P3 & $19,74 \mathrm{c}$ & $39,00 \mathrm{~b}$ & $70,33 \mathrm{~b}$ & $79,40 \mathrm{bc}$ \\
P4 & $21,20 \mathrm{~d}$ & $40,85 \mathrm{~b}$ & $69,13 \mathrm{~b}$ & $76,67 \mathrm{bc}$ \\
P5 & $18,73 \mathrm{~b}$ & $38,13 \mathrm{c}$ & $70,33 \mathrm{~b}$ & $78,60 \mathrm{bc}$ \\
P6 & $19,68 \mathrm{c}$ & $38,37 \mathrm{c}$ & $76,03 \mathrm{~b}$ & $81,27 \mathrm{c}$ \\
\hline
\end{tabular}

Keterangan: Angka-angka pada kolom yang sama yang diikuti huruf sama tidak berbeda nyata pada Uji Duncan 5\%

Tinggi tanaman kedelai terbaik pada pengamatan maksimal (9 MST) terdapat pada perlakuan P6 (300g/ha). Naskiah (2017) mengatakan bahwa pemupukan phonska berpengaruh nyata pada tinggi tanaman kedelai dengan dosis $300 \mathrm{~kg} / \mathrm{ha}$ berbeda nyata dengan kontrol, tetapi tidak berbeda nyata dengan dosis $200 \mathrm{~kg} / \mathrm{ha}$. Hal ini diduga karena rendahnya kandungan $\mathrm{N}$, di mana fungsi $\mathrm{N}$ dapat meningkatkan pertumbuhan vegetatif tanaman sehingga dosis $300 \mathrm{~kg} / \mathrm{ha}$ memberikan hasil tertinggi.

\section{Jumlah Daun}

Jumlah daun merupakan salah satu indikator pertumbuhan vegetatif tanaman. Semakin banyak jumlah daun tanaman maka proses fotosintesis yang terjadi dalam tanaman semakin banyak. Hasil pengamatan jumlah daun berdasarkan analisis ragam menunjukkan bahwa perlakuan pupuk NPK (10:26:10) berpengaruh nyata pada jumlah daun baik pada umur 3 MST, 5 MST, 7 MST, dan 9 MST (Tabel 2). 
Tabel 2. Jumlah Daun Tanaman Kedelai Varietas Argomulyo Akibat Pemberian Pupuk NPK

\begin{tabular}{ccccc}
\hline Perlakuan & \multicolumn{4}{c}{ Jumlah Daun } \\
\cline { 2 - 5 } & 3 MST & 5 MST & 7 MST & 9 MST \\
\hline P1 & $13,93 \mathrm{ab}$ & $20,77 \mathrm{a}$ & $26,57 \mathrm{a}$ & $32,53 \mathrm{a}$ \\
P2 & $17,13 \mathrm{bc}$ & $33,60 \mathrm{~b}$ & $47,77 \mathrm{~b}$ & $59,37 \mathrm{~b}$ \\
P3 & $18,10 \mathrm{c}$ & $29,67 \mathrm{~b}$ & $41,30 \mathrm{~b}$ & $53,90 \mathrm{~b}$ \\
P4 & $18,53 \mathrm{c}$ & $34,23 \mathrm{~b}$ & $46,10 \mathrm{~b}$ & $59,10 \mathrm{~b}$ \\
P5 & $15,00 \mathrm{abc}$ & $31,43 \mathrm{~b}$ & $46,37 \mathrm{~b}$ & $60,50 \mathrm{~b}$ \\
P6 & $16,07 \mathrm{abc}$ & $30,87 \mathrm{~b}$ & $44,90 \mathrm{~b}$ & $61,47 \mathrm{~b}$ \\
\hline
\end{tabular}

Keterangan : Angka-angka pada kolom yang sama yang diikuti huruf sama tidak berbeda nyata pada Uji Duncan 5\%

Pada akhir pengamatan (9 MST) jumlah daun tertinggi terdapat pada perlakuan P6 dengan hasil ratarata jumlah daun 61,47 helai tiap tanaman. Hal ini didukung oleh Naskiah (2017) bahwa aplikasi pupuk majemuk pada tanaman kedelai dengan dosis $300 \mathrm{~kg} / \mathrm{ha}$ menghasilkan jumlah daun sebanyak 23,90 helai bila dibanding kontrol dan dosis $200 \mathrm{~kg} / \mathrm{ha}$. Hal ini disebabkan karena rendahnya unsur $\mathrm{N}$ pada tanah, maka pupuk NPK yang diberikan langsung terserap oleh tanaman sehingga meningkatkan jumlah daun. Pada pemberian nitrogen dalam jumlah tinggi akan menyebabkan pertumbuhan vegetatif yang lebat dan warna daun menjadi hijau tua (Wahyudin, 2017).

\section{Jumlah Polong Isi}

Hasil analisis ragam pengaruh pupuk NPK terhadap jumlah polong kedelai menunjukkan pengaruh yang sangat berbeda nyata. Hasil jumlah polong kedelai tertinggi didapatkan pada perlakuan P6 (300 kg/ha NPK) yaitu 29,00 g diikuti dengan perlakuan P5 dengan berat 24,67 g, dan $\mathrm{P} 2, \mathrm{P} 3, \mathrm{P} 4$, dan $\mathrm{P} 1$ dengan ratarata masing-masing yaitu 24,00; 23,00; 22,33 dan 13,33 g (Gambar 1). Hal ini diduga karena penyerapan hara terutama unsur $\mathrm{P}$ yang berperan dalam meningkatkan produksi kedelai tersedia dan dapat diserap oleh tanaman secara maksimal. Menurut Permadi (2015) jumlah polong tiap tanaman dipengaruhi oleh dosis pupuk fosfor yang diberikan. Banyaknya polong yang terbentuk pada tanaman kedelai tanpa dipupuk fosfor lebih rendah 
dari pada tanaman yang dipupuk fosfor.

Pembentukan polong tergantung pada tingkat kelembaban tanah dan penyediaan unsur hara terutama fosfor dan kalsium untuk proses pembuahan dan pemasakan biji.

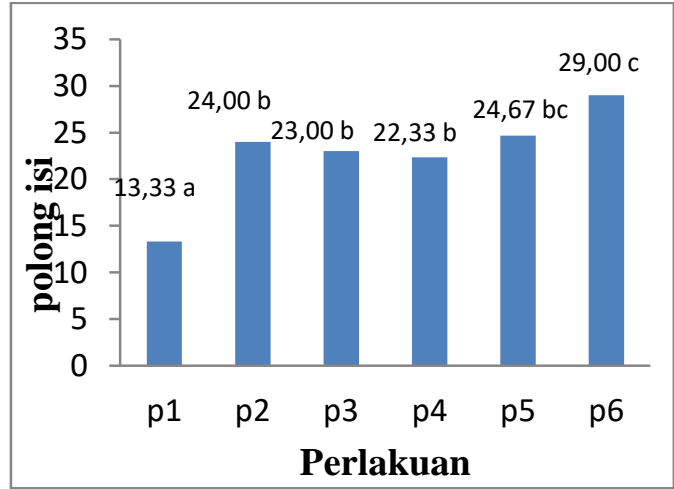

Gambar 1. Data Pengamatan Jumlah Polong Isi pada Tanaman Kedelai

Untuk memenuhi kebutuhan tanaman, unsur hara harus tersedia dalam jumlah yang seimbang agar tanaman dapat tumbuh dengan baik dan menghasilkan hasil yang tinggi.

\section{Berat 100 Biji Kedelai}

Berat 100 biji kedelai tertinggi pada perlakuan P6 (300 kg/ha NPK) yaitu 15,00 g diikuti dengan P2 dengan berat 14,23 g. Perlakuan P6 tidak berbeda dengan P5. Sementara P3 dan P4 tidak berbeda dengan kontrol (P1) (Gambar 2).
Pupuk yang diberikan pada tanaman kedelai cukup terserap oleh tanaman sehingga menghasilkan biji yang berat. Menurut Permadi (2015) fosfor dapat meningkatkan jumlah bunga yang terbentuk dan bobot kering biji kedelai. Produksi yang tinggi diduga karena tanaman mampu memanfaatkan $\mathrm{P}$ dan $\mathrm{K}$ yang tersedia dalam tanah. Hal ini sejalan dengan Naskiah (2017) bahwa pupuk majemuk NPK phonska berpengaruh terhadap berat 100 biji kedelai dengan dosis $300 \mathrm{~kg} / \mathrm{ha}(38,27)$ bila dibandingkan dengan kontrol atau tanpa perlakuan $(29,73 \mathrm{~g})$.

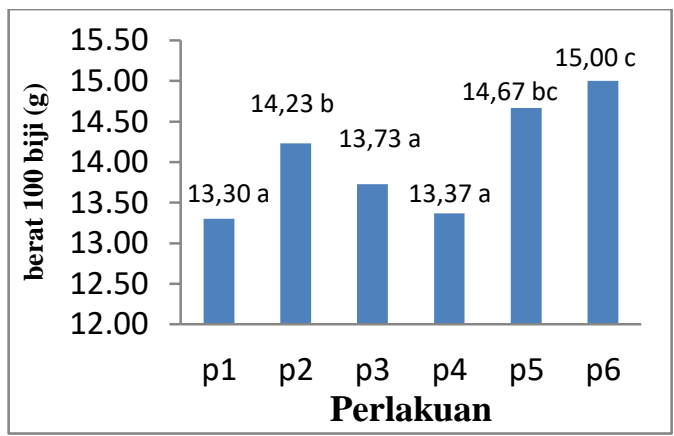

Gambar 2. Data Pengamatan Berat 100 biji (g) pada Tanaman Kedelai

Mimbar (2011) menyatakan bahwa selain nitrogen unsur hara fosfat juga dibutuhkan oleh tanaman. Hal ini terbukti bahwa pemberian fosfat melalui NPK dapat meningkatkan jumlah polong dan bobot biji kedelai. Peran fosfat sebagai regulator, pertumbuhan akar, 
sehingga tanaman dapat tumbuh tegak, kokoh dan daya jelajah akar menyebar dan mengambil air. Di dalam tubuh tanaman fosfor memberikan peranan yang penting dalam pembentukan bunga, buah dan biji. Gambar 2 menunjukkan berat 100 biji kedelai yang sudah optimum (> 12 gram). Hal ini berarti pembentukan biji sudah maksimal dan unsur hara yang tersedia dalam tanah diserap oleh tanaman secara maksimal.

\section{Kandungan N-Total Tanaman}

Pemberian pupuk majemuk

NPK dapat meningkatkan serapan N pada tanaman, tetapi pada perlakuan pupuk $\mathrm{N}$ yang lebih tinggi serapan $\mathrm{N}$ total mengalami penurunan. Hal ini disebabkan aktivitas penambatan nitrogen oleh bakteri Rhizobium yang menurun akibat kadar nitrogen dalam tanah yang tinggi. Menurut Sabilu (2015), adanya penambatan nitrogen yang dilakukan oleh Rhizobium pada tanaman kedelai dan senyawa nitrogen anorganik hasil dekomposisinya menyebabkan kandungan $\mathrm{N}$ dalam jaringan tanaman kedelai meningkat.

Tabel 3. Kandungan N-Total Tanaman Kedelai Varietas Argomulyo Akibat Pemberian Pupuk NPK

\begin{tabular}{ccc}
\hline Perlakuan & $\begin{array}{c}\text { N-total } \\
\text { tanaman }\end{array}$ & Kriteria \\
\hline P1 & $0,53 \mathrm{ab}$ & Rendah \\
P2 & $0,35 \mathrm{a}$ & Rendah \\
P3 & $0,58 \mathrm{~b}$ & Rendah \\
P4 & $0,50 \mathrm{ab}$ & Rendah \\
P5 & $0,54 \mathrm{ab}$ & Rendah \\
P6 & $0,57 \mathrm{ab}$ & Rendah \\
\hline
\end{tabular}

Keterangan:

Kriteria N tanah berdasarkan LPT (1983)

Angka-angka pada kolom yang sama yang diikuti huruf sama tidak berbeda nyata pada Uji Duncan 5\%

Pemberian $\mathrm{N}$ yang berlebihan akan meningkatkan $\mathrm{N}$ tersedia dalam tanah. Hal ini akan mempengaruhi jumlah dan berat bintil akar. Nitrat mempunyai kemampuan dalam perubahan bentuk rambut-rambut akar yang diperlukan bagi masuknya bakteria, sehingga mereduksi jumlah nodul dan mempengaruhi kegiatan nodula- 
nodula yang telah terbentuk dengan mereduksi volume jaringan bakteri dan dengan mempengaruhi keseimbangan karbohidrat dan nitrogen dalam tanaman.

\section{Kandungan $P$ total tanaman}

Kandungan $\mathrm{P}$ total tanaman kedelai tidak berbeda antar semua perlakuan yang ada.

Tabel 4. Kandungan P-total Tanaman Kedelai Varietas Argomulyo Akibat Pemberian Pupuk NPK

\begin{tabular}{ccc}
\hline Perlakuan & $\begin{array}{c}\text { P-total } \\
\text { tanaman }\end{array}$ & Kriteria \\
\hline P1 & 0,56 & Rendah \\
P2 & 0,67 & Rendah \\
P3 & 0,66 & Rendah \\
P4 & 0,66 & Rendah \\
P5 & 0,67 & Rendah \\
P6 & 0,69 & Rendah \\
\hline
\end{tabular}

Keterangan: Kriteria P tanah berdasarkan LPT (1983).

Angka-angka pada kolom yang sama yang diikuti huruf sama tidak berbeda nyata pada Uji Duncan 5\%

Pada tanaman muda, kadar $\mathrm{P}$ paling tinggi dijumpai pada pusatpusat pertumbuhan. Seperti halnya unsur $\mathrm{P}$ yaitu apabila tanaman mengalami defisiensi lebih dulu pada jaringan lebih tua. Demikian juga apabila tanaman sudah memasuki fase generatif (masak), sebagian besar P dimobilisasi ke biji dan buah atau bagian generatif tanaman. Kadar $\mathrm{P}$ bagian-bagian generatif tanaman biji lebih tinggi dibandingkan dengan bagian-bagian tanaman yang lain (Permadi., 2015).

\section{Kandungan K-Total Tanaman}

Tabel 5. menunjukkan bahwa kandungan $\mathrm{K}$ total tanaman kedelai tidak berbeda pada semua perlakuan pupuk NPK. 
Tabel 5. Kandungan K-total Tanaman Kedelai Varietas Argomulyo Akibat Pemberian Pupuk NPK

\begin{tabular}{ccc}
\hline Perlakuan & $\begin{array}{c}\text { K-total } \\
\text { tanaman }\end{array}$ & Kriteria \\
\hline P1 & 6,73 & Tinggi \\
P2 & 6,73 & Tinggi \\
P3 & 6,77 & Tinggi \\
P4 & 5,84 & Tinggi \\
P5 & 6,69 & Tinggi \\
P6 & 7,31 & Tinggi \\
\hline
\end{tabular}

Keterangan : *Kriteria N tanah berdasarkan LPT (1983).

Angka-angka pada kolom yang sama yang diikuti huruf sama tidak berbeda nyata pada Uji Duncan 5\%

Bila dibandingkan dengan penelitian lainnya yang dilaksanakan di tanah Inceptisol daerah Subang menunjukkan bahwa kebutuhan pupuk K untuk kedelai di tanah berstatus $\mathrm{K}$ rendah dan tinggi berturut-turut adalah 265 dan $165 \mathrm{~kg}$ $\mathrm{KCl} /$ ha (Rosmarkam, 2012).

\section{KESIMPULAN}

Tinggi tanaman dan jumlah daun kedelai pada tanaman yang diberi perlakuan pupuk NPK tidak berbeda, tetapi tanaman lebih tinggi dan jumlah daunnya lebih banyak dibanding perlakuan kontrol.

Jumlah polong berisi dan berat 100 biji kedelai pada perlakuan P6 tidak berbeda dengan perlakuan P5, tetapi berbeda dengan perlakuan P2 dan P3.

\begin{abstract}
SARAN
Perlu dilakukan penelitian lanjut dengan dosis NPK lebih tinggi dari dosis pupuk NPK yang dicoba karena grafik pertumbuhan tanaman dan produksi kedelai Varietas Argomulyo masih naik terus, belum mencapai pertumbuhan maksimal. Kadar serapan N-total, Ptotal dan K-total juga perlu dianalisa pada biji kedelai.
\end{abstract}

\section{DAFTAR PUSTAKA}

BPS, 2019.

www.bps.go.id/kebutuhankedelai-di-indonesia-tahun2019. Diakses pada tanggal 20 September 2019.

Hadie, J., B. Guritno, H.T. Sebayang, dan E. Handayanto. 2013. Pengaruh Pembubuhan Pupuk NPK Terhadap Keragaan Kacang Tunggak dan Karakteristik Pertumbuhan Rhizobium di 
Lahan Lebak. Agroseintiae 26:10- 15 .

Manshuri, A. G. 2013. Pemupukan $\mathrm{N}$, P, dan $\mathrm{K}$ pada Kedelai Sesuai Kebutuhan Tanaman dan Daya Dukung Lahan. Jurnal Penelitian Pertanian Tanaman Pangan. 29 (3): 171179.

Mimbar, S. M. 2011. Pemupukan NUrea Melalui Daun Pada Kedelai Wilis. Agrivita Vol. 13.

Naskiah. 2017. Pengaruh Inokulasi Rhizobium dan Waktu Pemberian Pupuk N (Urea) terhadap Pertumbuhan dan Hasil Kedelai Di Lahan Sawah Setelah Kedelai (Glycine max (L). Merril).

Permadi, K. dan Hariyati, Y. 2015. Pemberian Pupuk N, P, dan K Berdasarkan Pengelolaan Hara Spesifik Lokasi Untuk Meningkatkan Produktivitas Kedelai. Fakultas Pertanian Universitas Udayana: Denpasar Bali-Indonesia. AGROTROP. 5 (1): 1-8.

Pringgohandoko, B. dan O.S. Padmini. 2015. Pengaruh Rhizo-plus dan Pemberian Cekaman Air Selama Stadia Reproduksi terhadap Hasil dan Kualitas Biji Kedelai. Agrivet. Vol 1.

Rosmarkam, A dan N. Yuwono, N. 2002. Ilmu Kesuburan Tanah. Kanisius. Yogyakarta.

Sabilu.Y, Damhuri, Imran. 2015. Kadar N, P, Dan K Kedelai (Glycine max (L) Merril) yang
Diaplikasi Azotobacter, sp., Mikoriza dan Pupuk Organik. Biowallacea. 2(1): 153-161.

Wahyudin, A., F.Y. Wicaksono, A.W. Irwan, Ruminta, and R. Fitriani. 2017. Respons Tanaman Kedelai (Glycine max) Varietas Wilis Akibat Pemberian Berbagai Dosis Pupuk N, P, K, dan Pupuk Guano pada Tanah Inceptisol Jatinangor. Jurnal Kultivasi 16(2). 